\title{
EFFECT OF LIPID PARAMETERS ON FOETAL GROWTH IN GESTATIONAL DIABETES MELLITUS PREGNANCIES
}

\section{Slagjana Simeonova-Krstevska ${ }^{1}$, Brankica Krstevska ${ }^{2}$, Valentina Velkoska-Nakova ${ }^{3}$, Marija Hadji Lega ${ }^{1}$, Igor Samardjiski ${ }^{1}$, Vladimir Serafimoski ${ }^{4}$, Vesna Livrinova ${ }^{1}$, Irena Todorovska ${ }^{1}$, Aneta Sima ${ }^{1}$}

\footnotetext{
${ }^{1}$ Medical Faculty, Obstetrics and Gynecology Clinic, Skopje, Macedonia

${ }^{2}$ Medical Faculty, Endocrinology Clinic, Skopje, Macedonia

${ }^{3}$ Faculty of Medical Science, Goce Delchev University, Shtip, Macedonia

${ }^{4}$ Macedonian Academy of Sciences and Arts, Skopje, Macedonia
}

Corresponding Author: Slagjana Simeonova Krstevska, Obstetrics and Gynaecology Clinic, Skopje, R. Macedonia, Faculty of Medicine, 1000 Skopje, R. Macedonia, Mob.+ 389 (0)2 0707868 59, E-mail: simeonovas@yahoo.com

\begin{abstract}
Introduction: Women with gestational diabetes mellitus (GDM) often deliver newborns large for their gestational age (LGA). The aim of the study was to evaluate the effect of lipid parameters in the second half of pregnancy on foetal growth in GDM pregnancies.

Material and methods: In two hundred consecutive women with GDM the age, body mass index before pregnancy, body mass index before delivery, gestational week of GDM diagnosis, lipid parameters after 24 weeks of pregnancy, fasting glycaemia, HbAlc in the second and third trimester of pregnancy, gestational age at delivery, mode of delivery, and baby birth weight were analyzed.

Results: Of the 200 GDM pregnancies, 50 (25\%) women delivered LGA newborns, 135 (67.5\%) women delivered newborns appropriate for gestational age (AGA), and 15 (7.5\%) women delivered newborns small for gestational age (SGA). Maternal triglyceride levels and HbAlc in the second trimester were higher, and HDL-C was significantly lower, in the LGA group than in the AGA group $(3.8 \pm 1.8$ vs. $3.1 \pm 1.1 \mathrm{mmol} / \mathrm{L}, 6.1 \pm 1.1$ vs. $5.5 \pm 0.8 \%$, and $1.3 \pm 0.4$ vs. $1.6 \pm 0.4 \mathrm{mmol} / \mathrm{L}, \mathrm{p}<$ $0.05)$. Also, maternal triglyceride levels and $\mathrm{HbA} 1 \mathrm{c}$ in the second trimester were significantly higher in the SGA group than in the AGA group $(3.8 \pm 1.9 \mathrm{vs} .3 .1 \pm 1.1 \mathrm{mmol} / \mathrm{L}$ and $6.8 \pm 0.8 \mathrm{vs} .5 .5 \pm$ $0.8 \%, \mathrm{p}<0.05)$. Maternal triglycerides were independent predictors for delivering LGA newborns in GDM women.

Conclusion: In GDM pregnancies, maternal triglycerides in the second half of pregnancy may indentify women who will deliver LGA newborns. Thus, with good regulation of lipid profile, we can avoid macrosomia from GDM pregnancies.
\end{abstract}

Key words: lipid parameters, triglycerides, gestational diabetes mellitus, large for gestational age newborns.

Introduction

Maternal lipid metabolism is altered during pregnancy with increased tissue lipolysis and associated hyperlipidaemia [1, 2]. Hyperlipidaemia is common in the second half of pregnancy as a physiologically required mechanism to maintain stable fuel supplementation to the foetus [3]. In normal pregnancy, as the pregnancy progresses, there is evidence of reference values for lipids according to gestational weeks [4].

It is known that women with gestational diabetes mellitus (GDM) often deliver newborns large for their gestational age (LGA). This is due to maternal hyperglycaemia, but there is evidence that not only glucose but also disturbance in the maternal lipid metabolism may contribute to foetal overgrowth [5]. 
Variation of birth weight is strongly determined by neonatal fat mass, and it is likely that foetal growth disorders might also result from variations in maternal and foetal lipid metabolism. In nondiabetic pregnancies, maternal triglycerides have been shown to be correlated with birth weight $[4,6-8]$.

The aim of the study was to evaluate the effect of lipid parameters in the second half of pregnancy on foetal growth in GDM pregnancies.

\section{Material and methods}

Two hundred consecutive women with GDM who visited the Outpatient Department of the University Endocrinology, Diabetes and Metabolic Disorders Clinic were analysed. All were with singleton pregnancies, and the neonates were delivered at the University Gynaecology and Obstetrics Clinic. The criteria for GDM were at least one out of three abnormally high plasma glucose value measurements during the 2-hour $75 \mathrm{~g}$. oral glucose tolerance test (OGTT) (normal values: fasting level $<5.1,1$-h level $<10.0,2$-h level $<8.5 \mathrm{mmol} / \mathrm{L})$. Venous blood glucose levels were measured by glucose oxidase (Glucose Analyzer; Beckman, Brea, CA).

In the second half of pregnancy maternal fasting serum triglycerides, total cholesterol (TCh), high-density lipoprotein (HDL-C), and low-density lipoprotein cholesterol (LDL-C) levels were determined. Maternal HbAlc in the second and third trimester of pregnancy were measured. The BMI of women with GDM was calculated by dividing the weight by the height squared (kilograms $/$ metres $^{2}$ ). Pre-pregnancy body mass index (BMI 1) was calculated from selfreported pre-pregnancy height and weight. Predelivery body mass index (BMI 2) was measured on delivery admission day in the University Gynecology and Obstetrics Clinic. The gestational age was estimated from the date of the last menstrual period (all patients had regular menstrual cycles). The babies' birth weights were classified as LGA, appropriate for gestational age (AGA), and small for gestational age (SGA). We defined LGA as a birth weight above the 90th percentile, SGA as a birth weight below the 10th percentile for gestational age and AGA between the two.
Blood samples for $\mathrm{HbA1c}$ and lipid assessment were taken after overnight fasting. The blood samples for lipoproteins were analyzed using Cobas Integra 700, according to standard methods. TCh and triglycerides were determined by full enzymatic methods (TCh-CHODPOD-PAP and triglycerides-GPO; Cobas Integra 700, Hoffmann-La Roche, Basel, Switzerland). HDL-C was measured by the polyanion precipitation method, while LDL-C was calculated using the Friedewald formula. LDL-C were fractioned using ultracentrifugation in cases of triglycerides exceeding $4 \mathrm{mmol} / \mathrm{l}$. HbAlc was measured by an ionexchange HPL-C instrument (DS5; Drew, USA) with a reference range of $4.2-6 \%$.

The study was carried out according to the Declaration of Helsinki.

Statistical analyses were performed using SPSS software for Windows, version 14.0. For analysis, t-test, Chi-square test, correlation, and linear multiple regression were used. $p<0.05$ was considered statistically significant.

\section{Results}

Of the 200 GDM pregnancies, $50(25 \%)$ women delivered LGA newborns, 135 (67.5\%) women delivered appropriate for gestational age (AGA) newborns, and 15 (7.5\%) women delivered small for gestational age (SGA) newborns. The characteristics among women who delivered LGA, AGA, and SGA newborns are shown in Table1.

Maternal BMI 1 and BMI 2 were signifycantly higher in the LGA group than in the AGA and SGA groups $(28.4 \pm 6.1$ vs. $26.5 \pm$ $4.9,28.4 \pm 6.1$ vs. $25.0 \pm 4.6$, and $33.1 \pm 6.1$ vs. $31.1 \pm 4.9,33.1 \pm 6.1$ vs. $29.3 \pm 4.4 \mathrm{~kg} / \mathrm{m}^{2}$, respectively, $\mathrm{p}<0.05)$. Maternal triglyceride levels and $\mathrm{HbAlc}$ in the second trimester were significantly higher, and HDL-C was significantly lower in the LGA and SGA groups than in the AGA group (Table 1, $\mathrm{p}<0.05$ ). The percentage of caesarean section in the SGA group was significantly lower than in the LGA and AGA groups, but it was not different between LGA and AGA groups. Gestational weeks of delivery were lower in the SGA group, and higher in the LGA group. 
Table 1

Comparison of characteristics between women with GDM who delivered LGA, AGA, and SGA newborns

\begin{tabular}{|c|c|c|c|c|c|c|}
\hline & $\begin{array}{c}\text { LGA } \\
\mathbf{n}=\mathbf{5 0}\end{array}$ & $\begin{array}{c}\text { AGA } \\
n=135\end{array}$ & $\begin{array}{c}\text { SGA } \\
\mathrm{n}=15\end{array}$ & $\begin{array}{c}p \\
\text { (LGA vs. AGA) }\end{array}$ & $\begin{array}{c}p \\
\text { (LGA vs. SGA) }\end{array}$ & $\begin{array}{c}p \\
\text { (AGA vs. SGA) }\end{array}$ \\
\hline Age (years) & $31.4 \pm 5.6$ & $31.1 \pm 5.6$ & $32.9 \pm 5.1$ & NS & NS & NS \\
\hline BMI_1 $\left(\mathrm{kg} / \mathrm{m}^{2}\right)$ & $28.4 \pm 6.1$ & $26,5 \pm 4.9$ & $25.0 \pm 4.6$ & 0.029 & 0.011 & NS \\
\hline BMI_2 $\left(\mathrm{kg} / \mathrm{m}^{2}\right)$ & $33.1 \pm 6.1$ & $31,1 \pm 4.9$ & $29.3 \pm 4.4$ & 0.039 & 0.030 & NS \\
\hline $\begin{array}{l}\text { Total lipids } \\
\text { (mmol/L) }\end{array}$ & $11.0 \pm 2.1$ & $10.8 \pm 2.0$ & $11.4 \pm 2.4$ & NS & NS & NS \\
\hline $\begin{array}{l}\text { Triglicerides } \\
(\mathrm{mmol} / \mathrm{L})\end{array}$ & $3.8 \pm 1.8$ & $3.1 \pm 1.1$ & $3.8 \pm 1.9$ & 0.012 & NS & 0.012 \\
\hline TCh (mmol/L) & $6.0 \pm 1.0$ & $6.5 \pm 1.4$ & $6.3 \pm 1.3$ & NS & NS & NS \\
\hline HDL-C (mmol/L) & $1.3 \pm 0.4$ & $1.6 \pm 0.4$ & $1.5 \pm 0.5$ & 0.001 & NS & NS \\
\hline LDL-C (mmol/L) & $3.8 \pm 1.0$ & $3.5 \pm 1.2$ & $3.7 \pm 1.4$ & NS & NS & NS \\
\hline $\begin{array}{l}\begin{array}{l}\text { Glucaemia } \\
(\mathrm{mmol} / \mathrm{L})\end{array} \\
\end{array}$ & $5.5 \pm 1.4$ & $5.2 \pm 1.1$ & $5.4 \pm 1.3$ & NS & NS & NS \\
\hline HbA1c 2nd (\%) & $6.1 \pm 1.1$ & $5.5 \pm 0.8$ & $6.8 \pm 0.8$ & 0.032 & 0.0003 & 0.0003 \\
\hline HbA1c 3th (\%) & $6.1 \pm 1.2$ & $5.7 \pm 1.0$ & $6.0 \pm 0.8$ & NS & NS & NS \\
\hline $\begin{array}{l}\text { B. Birth Weight } \\
\text { (grams) }\end{array}$ & $4390 \pm 332$ & $3345 \pm 424$ & $2358 \pm 423$ & $<0.0001$ & $<0.0001$ & $<0.0001$ \\
\hline $\begin{array}{l}\text { Gest age at diag. } \\
\text { (weeks) }\end{array}$ & $28.6 \pm 7.7$ & $28.0 \pm 7.1$ & $23.8 \pm 7.6$ & NS & 0.040 & 0.040 \\
\hline $\begin{array}{l}\text { Mode of delivery } \\
\text { (caesarean section)* }\end{array}$ & $45(90 \%)^{*}$ & $118(87.5 \%)^{*}$ & $7(47.7 \%)^{*}$ & NS* & $0.0005^{*}$ & $0.0005^{*}$ \\
\hline $\begin{array}{l}\text { Gest week of } \\
\text { delivery }\end{array}$ & $39.3 \pm 1.5$ & $38.2 \pm 1.9$ & $36.4 \pm 3.7$ & 0.001 & 0.0001 & 0.002 \\
\hline
\end{tabular}

Given data are means $\pm \mathrm{SD}$, t-test was used

*given data are percentages, chi-square was used

Maternal triglycerides statistically significantly correlated with BMI 1 and $\mathrm{HbA} 1 \mathrm{c}$ in the second trimester $(\mathrm{r}=0.25, \mathrm{p}=0.07$ and $\mathrm{r}=$ $0.31, \mathrm{p}=0.04)$. No significant correlation was found between maternal triglycerides and baby birth weight $(\mathrm{r}=0.16, \mathrm{p}=0.077)$, but $p$ value was close to statistical significance. Baby birth weight correlated statistically significantly with HbAlc in the second trimester $(\mathrm{r}=0.30, \mathrm{p}=$ $0.04)$.

Table 2
Univariant analysis showed a statistical significance between baby birth weight and BMI 1, BMI 2, HbA1c in the second trimester, HDL-C and triglycerides.

To determine independent predictors of LGA we used linear multiple regression analysis with LGA as a dependent variable. Analysis (Table 2) showed that triglycerides were independent predictors for delivering LGA newborns in GDM women.

Dependent variable: LGA

Predictors of LGA newborns in GDM pregnancies

\begin{tabular}{|l|c|c|c|}
\hline & $\begin{array}{c}\text { Standardized } \\
\text { coefficients Beta }\end{array}$ & $\mathrm{t}$ & P value \\
\hline (Constant) & & 0.339 & 0.737 \\
\hline BMI 1 & -0.089 & -0.229 & 0.820 \\
\hline BMI 2 & 0.039 & 0.101 & 0.920 \\
\hline Triglicerides & 0.326 & 2.077 & 0.045 \\
\hline TCh & -0.230 & -1.419 & 0.164 \\
\hline HbA1c II trimester & 0.165 & 1.026 & 0.312 \\
\hline
\end{tabular}

\section{Discussion}

The results of the study showed that triglycerides in the second half of pregnancy and
$\mathrm{HbA} 1 \mathrm{c}$ in the second trimester were significant risk factors for delivering LGA newborns in GDM pregnancies. 
It is known that maternal obesity is a major risk factor for LGA newborns especially in GDM pregnancies [9-11]. Our results confirm this. Women who delivered LGA newborns had a higher BMI 1 and BMI 2. But later triglyceride levels were shown as predictors for LGA, independently of BMI.

Our findings are in accordance with those of Kitijama et al. and Knopp et al. [4, 6], who showed that high maternal triglyceride levels predicted macrosomia independently of maternal BMI. Schaefer-Graf et al. [12] demonstrated that maternal lipids were strong determinants of foetal growth in pregnant women with GDM. In arterial cord blood serum they found higher free fatty acids levels in women with GDM. Our study confirms that triglycerides were significantly higher and an independent predictor for LGA in GDM pregnancies. They can predict LGA newborns independently of maternal BMI 1, BMI 2, and HbAlc in the second trimester of pregnancy. These results suggest including lifestyle programmes for women of reproductive age with a focus on lowering triglyceride levels: diet, weight reduction, and physical activity. Routine measurement of maternal serum triglyceride levels at the beginning of the second half of pregnancy may show women who have acquired an adequate and balanced diet.

A statistically significant positive correlation between triglycerides and baby birth weight was not found, but $\mathrm{p}$ value $(\mathrm{p}=0.07)$ was very close to significance. Maybe in a larger population this correlation will be statistically significant.

The mechanism by which pregnancy alters lipid metabolism is not fully understood. Oestrogens can increase levels of triglycerides by stimulating hepatic production of very low density lipoproteins and by inhibition of hepatic and adipose tissue lipoprotein lipase. Progesterone has the opposite action on lipoprotein metabolism. It has therefore been suggested that the oestrogen-progesterone ratio is higher in the second half of pregnancy and that explains the higher triglyceride levels as pregnancy progresses. Triglyceride clearance is reduced due to decreased lipoprotein lipase activity [3]. These changes coincide with reduced insulin sensitivity, which may also contribute to the increase in triglycerides. Because maternal triglyceride does not cross the placenta, enhanced insulin resistance in GDM pregnancies may explain the relationship between maternal triglyceride levels and foetal growth [13]. The statistically significant correlation between triglycerides and BMI 1, and between triglycerides and $\mathrm{HbAlc}$ in the second trimester, can be explained by decreased insulin sensitivity, which is already known and has been shown in previous studies in women with GDM.

Surprisingly, only $\mathrm{HbAlc}$ in the second trimester, not in the third trimester, was statistically significantly higher in the LGA and SGA groups than in the AGA group. HbA1c in the third trimester was also higher in the LGA and SGA groups than in the AGA group, but without statistical significance. Maybe good glycaemic control in the third trimester of pregnancy is responsible for lowering the HbAlc in the LGA and SGA groups.

Triglyceride levels in the SGA group were statistically significantly higher than in the AGA group. This cannot be explained by BMI, because these groups were not significantly different in BMI 1 or BMI 2. SchaeferGraf UM et al. [12] also found significantly higher triglycerides in SGA newborns compared with AGA or LGA newborns. They explain these results by endothelial dysfunction in the placenta. Endothelial dysfunction in the placenta is reported to be associated with maternal complications and newborns' growth retardation. Increasing evidence suggests that elevated plasma lipids, including triglycerides or their related remnants, may induce endothelial dysfunction [14]. Increased peroxidation of these elevated plasma lipids causes enhanced oxidative stress by progressively producing free radicals and lipid peroxides. Lipid peroxides are toxic compounds that have the potential to damage endothelial cells [15].

Catov et al. [16] showed that high cholesterol or triglycerides before the 15 gestational weeks were associated with a 2.0 -fold increased risk for preterm birth. They propose maternal hyperlipidaemia could increase the oxidative stress in the foetus resulting not only in vessel wall damage, but also in disruption of normal placentation. Infection and inflammation induce the acute-phase response, leading 
to multiple alterations in lipid and lipoprotein metabolism, especially hypertriglyceridaemia [17]. So, inflammation, subclinical infection, and some metabolic factors such as hypertriglyceridaemia and obesity in pregnancy are associated with preterm birth risk. This could be the explanation for higher triglycerides, HDL-C, and early delivery in women with GDM which deliver SGA newborns. Maybe the effect on the placenta is different in different periods of pregnancy. In early pregnancy triglycerides affect vascular development and in late pregnancy they have a direct harmful effect on the endothelium of placental vasculature. But we did not analyse lipid parameters in different periods of pregnancy to confirm this.

Excessive mother to foetus glucose transfer increases not only the risk of large, but also the risk of small for gestational age newborns [18]. In our study women who delivered SGA newborns had a statistically significant higher $\mathrm{HbAlc}$ in the second trimester in comparison with AGA. Thus GDM increases the risk of LGA and also the risk of SGA newborns.

Time of delivery was significantly differrent in the three study groups, but all were in term. Surprisingly, LGA were delivered in normal term, but statistically significantly later than AGA.

We were not able to explain the higher percentage of section cesarean in the AGA group. Maybe the fact of existing GDM was responsible for the high percentage.

Additional studies which compare the lipid parameters in different pregnancy periods and their contribution to foetal growth are needed to give true answers.

\section{Conclusion}

In GDM pregnancies, maternal triglycerides in the second half of pregnancy may indentify women who will deliver LGA newborns. Thus, with a good regulation of lipid profile we can avoid macrosomia in GDM pregnancies.

\section{REFERENCES}

1. Vahratian A, Misra VK, Trudeau S, Misra DP. Prepregnancy body mass indexand gestational agedependent changes in lipid levels during pregnancy. Obstet Gynecol. 2010; 116: 107-113.
2. Koukkou E, Watts GF, Lowy C. Serum lipid, lipoprotein and apolipoproteinchanges in gestational diabetes mellitus: a cross-sectional and prospectivestudy. J Clin Pathol. 1996; 49: 634-637.

3. Wiznitzer A, Mayer A, Novack V, Sheiner E, Gilutz $\mathrm{H}$, Malhotra A, et al. Association of lipid levels during gestation with preeclampsia and gestational diabetes mellitus: a population-based study. Am J Obstet Gynecol. 2009; 201: 482e1-488.

4. Knopp RH, Magee MS, Walden CE, Bonet B, Benedetti TJ. Prediction of infant birth weight by GDM screening: importance of triglyceride. Diabetes Care. 1992; 15: 1605-1613.

5. Schaefer-Graf U.M, Meitzner K, Oretga-Senovilla H, Graf K, Vetter K, Abou-Dakn M, et al. Differences in the implications of maternal lipids on fetal metabolism and growth between gestational diabetes mellitus and control pregnancies. Diabet. Med. 2011; 1053-1059.

6. Kitajima M, Oka S, Yasuhi IFM, Rii Y, Ishimaru T. Maternal serum triglyceride at 24-32 weeks' gestation and newborn weight in nondiabetic women with positive diabetic screens. Obstet Gynecol. 2001; 97: 776-780.

7. Nolan C, Riley S, Sheedy M, Walstab J, Beischer N. Maternal serum triglyceride, glucose tolerance, and neonatal birth weight ratio in pregnancy. Diabetes Care. 1995; 18: 1550-1556.

8. Di Cianni G, Miccoli R, Volpe L, Lencioni C, Ghio A, Giovannitti M, et al. Maternal triglyceride levels and newborn weight in pregnant women with normal glucose tolerance. Diabet Med. 2005; 22: 21-25.

9. Clausen T, Burski TK, Oyen N, Godang K, Bollerslev J, Henriksen T. Maternal anthropometric and metabolic factors in the first half of pregnancy and risk of neonatal macrosomia in term pregnancies. A prospective study. European Journal of Endocrinology. 2005; 153: 887-894.

10. Ben-Haroush A, Hadar E, Chen R, Hod M, Yogev Y. Maternal obesity is a major risk factor for large-forgestational-infants in pregnancies complicated by gestational diabetes. Arch Gynecol Obstet. 2009; 279: 539-543.

11. Schaefer-Graf UM, Kjos SL, Kilavuz O, Plagemann A, Brauer M, Dudenhausen JW, et al. Determinants of Fetal Growth at Different Periods of Pregnancies Complicated by Gestational Diabetes Mellitus or Impaired Glucose Tolerance. Diabetes Care. 2003; 26(1): 193-198.

12. Schaefer-Graf UM, Graf K, Kulbacka I, Kjos SL, Dudenhausen J, Vetter K, et al. Maternal lipids as strong determinants of fetal environment and growth in pregnancies with gestational diabetes mellitus. Diabetes Care. 2008; 31(9):1858-1863.

13. Son GH, Kwon JY, Kim YH, Park YW. Maternal serum triglycerides as predictive factors for large-forgestational age newborns in women with gestationl diabetes mellitus. Acta Obstetricia et Gynecologica. 2010; 89: 700-704. 
14. Sattar N, Petrie JR, Jaap AJ. The atherogenic lipoprotein phenotype and vascular endothelial dysfunction. Atherosclerosis. 1998; 138: 229-235.

15. Vrijkotte TG, Krukziener N, Hutten BA, Vollebregt $\mathrm{KC}$, van Eijsden M, Twickler MB. Maternal lipid profile during early pregnancy and pregnancy complications and outcomes: the ABCD study. J Clin Endocrinol Metab. 2012; 97(11): 3917-3925.

16. Catov JM, Bodnar LM, Kip KE, Hubel C, Ness RB, Harger $\mathrm{G}$, et al. Early pregnancy lipid concentrations and spontaneous preterm birth. Am J Obstet Gynecol. 2007; 197: 610.e1-617.e1

17. Khovidhunkit W, Kim MS, Memon RA, Shigenaga $\mathrm{JK}$, Moser $\mathrm{AH}$, Feingold $\mathrm{KR}$, et al. Effects of infection and inflammation on lipid and lipoprotein metabolism: mechanisms and consequences to the host. J Lipid Res. 2004; 45: 1169-1196.

18. Crowther C, Hiller J, Moss J, McPhee A, Jeffries W, Robinson J. Effect of treatment of gestational diabetes mellitus on pregnancy outcomes. N Engl J Med. 2005; 352: 2477-2486.

Резиме

\section{ВЛИЈАНИЕ НА ЛИПИДНИТЕ} ПАРАМЕТРИ ВРЗ ФЕТАЛНИОТ РАСТ КАЈ БРЕМЕНИ СО ГЕСТАЦИСКИ ДИЈАБЕТЕС

\section{Слаѓана Симеонова-Крстевска ${ }^{1}$, Бранкица Крстевска ${ }^{2}$, Валентина Велкоска-Накова ${ }^{3}$, Марија Хаџи Лега ${ }^{1}$, Игор Самарџиски ${ }^{1}$, Владимир Серафимоски ${ }^{4}$, Весна Ливринова ${ }^{1}$, Ирена Тодоровска $^{1}$, Анета Сима ${ }^{1}$}

${ }^{1}$ Клиника за гинекологија и акушерство, Медицински факултет, Универзитет „Кирил и Методиј“, Скопје, Р. Македонија ${ }^{2}$ Клиника за ендокринологија и болести на метаболизмот, Медицински факултет, Универзитет „Кирил и Методиј“, Скопје, Р. Македонија

${ }^{3}$ Факултет за медицински науки, Универзитет „Гоце Делчев“, Штип, Р. Македонија

${ }^{4}$ Македонска академија на науките и уметностите, Скопје, Р. Македонија

Вовед: Жените со гестациски дијабетес мелитус (ГДМ) често раѓаат новородени големи за гестациската возраст (ЛГА). Цел на студијата беше да го евалуираме влијанието на липидните параметри во втората половина на бременоста врз феталниот раст кај жени со ГДМ.

Майеријал и мейоди: Кај 200 жени со дијагностициран ГДМ последователно беа анализирани следниве параметри: возраст, индекс на телесна маса (ИТМ) пред забременување, ИТМ пред породување, гестациска недела на дијагноза на ГДМ, липидни параметри по 24. недела од бременоста, гликемија на гладно, гликолизиран хемоглобин (HbA1c) во второто и во третото тримесечје од бременоста, гестациска недела на породување, начин на породување и родилна тежина на новороденото.

Резулйайи: Од 200 бремености со ГДМ, 50 (25\%) жени родија новородено ЛГА, 135 (67,5\%) родија новородено соодветно за гестациската возраст (АГА) и $15(7,5 \%)$ родија новородено мало за гестациската возраст (СГА). Мајчините триглицериди и $\mathrm{HbAlc}$ во второто тримесечје од бременоста беа повисоки и HDL-C беше значајно понизок во групата жени што родиле новородено ЛГА во споредба со жените што родиле новородено АГА $(3,8 \pm 1,8$ vs. $3,1 \pm 1,1$ $\mathrm{mmol} / \mathrm{L}, 6,1 \pm 1,1$ vs. $5,5 \pm 0,8 \%$ и $1,3 \pm 0,4$ vs. $1,6 \pm 0,4 \mathrm{mmol} / \mathrm{L}, \mathrm{p}<0,05)$. Исто така, мајчините триглицериди и $\mathrm{HbA1c}$ во второто тримесечје од бременоста беа значајно повисоки кај жените што родиле новородено СГА во споредба со жените што родиле новородено АГА $(3,8 \pm 1,9$ vs. $3,1 \pm 1,1 \mathrm{mmol} / \mathrm{L}$ и $6,8 \pm 0,8$ vs. $5,5 \pm 0,8 \%$, p $<$ $0,05)$. Мајчините триглицериди беа независни предиктори за раѓање новородено ЛГА кај жени со ГДМ.

Заклучок: Кај бременост со ГДМ, мајчините триглицериди во втората половина на бременоста може да ги идентификуваат жените што ќе родат новородено ЛГА. Затоа, со добра регулација на липидниот профил може да се избегне макросомија од бременостите со ГДМ.

Клучни зборови: липидни параметри, триглицериди, гестациски дијабетес, новородени големи за гестациската возраст. 